A C T A UN IVER S T A T IS N I C O L A I C O P E R N I C I

\title{
Karolina Lewandowska-Gwarda*
}

\section{ROLA PRZESTRZENI W BADANIACH EKONOMICZNYCH}

Z a rys tre ści. Celem artykułu jest podkreślenie i uzasadnienie istotności uwzględniania czynnika przestrzeni (rozumianej jako położenie geograficzne, sąsiedztwo, odległość badanych jednostek przestrzennych) w badaniach ekonomicznych. W opracowaniu podjęto próbę usystematyzowania hipotez powstających $\mathrm{w}$ ramach głównego nurtu ekonomii przestrzennej, regionalistyki oraz nowej ekonomii geograficznej, które dały impuls do rozwoju współczesnej metodologii analiz przestrzennych.

S ło w a k l u c z o w e: przestrzeń, ekonomia przestrzenna, analiza danych przestrzennych.

K l a s y i k a c j a J E L: A11, C21, N01, R10.

„Uwzględnienie przestrzeni nie zmienia szczegótów... ale zmienia wszystko. Przestrzeń nie jest ekonomicznie neutralna".

C. Ponsard

\section{WSTĘP}

Koniec XX i początek XXI w. to okres, w którym niezwykle szybko zaczęły rozwijać się dziedziny wiedzy, takie jak ekonomia przestrzenna, regionalistyka, nowa ekonomia geograficzna, eksploracyjna analiza danych przestrzennych oraz statystyka i ekonometria przestrzenna. Dyscypliny te w swoich teoriach i analizach biorą pod uwage aspekty przestrzenne badanych zjawisk ekonomicznych, tj. położenie geograficzne, sąsiedztwo, odległość od innych obszarów.

Przestrzeń i fakt usytuowania w określonej lokalizacji geograficznej ma bardzo duży wpływ na kształtowanie się różnorodnych zjawisk i procesów ekonomiczno-społecznych. Zrozumienie związków przestrzennych zachodzących pomiędzy jednostkami terytorialnymi (krajami, regionami, województwami itd.) jest kluczem do zrozumienia praw rządzących współczesną ekonomią

\footnotetext{
* Adres do korespondencji: Karolina Lewandowska-Gwarda, Katedra Ekonometrii Przestrzennej, Wydział Ekonomiczno-Socjologiczny UŁ, ul. Rewolucji 1905 r. 37, 90-214 Łódź; adres e-mail: lewandowska@uni.lodz.pl.

(C) 2013 Nicolaus Copernicus University Press. All rights reserved. http://www.aunc.ekonomia.umk.pl
} 
światową. Z tego względu w literaturze przedmiotu jest obecnie obserwowane rosnące zainteresowanie tą tematyką, jest podkreślana rola metod i modeli ekonomii i ekonometrii przestrzennej w badaniach ekonomicznych. Zastosowanie tych narzędzi umożliwia bowiem odpowiednią analizę nasilających się w ostatnich latach zjawisk, tj. pogłębiających się nierówności w rozwoju gospodarczym regionów; rozwoju dominujących aglomeracji na świecie; dyfuzji innowacji, informacji i ludzi; wymiany międzynarodowej dóbr i usług; systematycznie zwiększających się kosztów handlu; lokalizacji działalności gospodarczych $\mathrm{w}$ określonych rejonach świata; przestrzennego skupiania się ludności, biznesu, bogactwa, jak również ubóstwa na świecie.

Celem artykułu jest podkreślenie i uzasadnienie istotności uwzględniania czynnika przestrzeni ${ }^{1} \mathrm{w}$ badaniach ekonomicznych. W opracowaniu podjęto próbę usystematyzowania hipotez powstających w ramach głównego nurtu ekonomii przestrzennej, regionalistyki oraz nowej ekonomii geograficznej, które dały impuls do rozwoju współczesnej metodologii analiz przestrzennych.

\section{CO Z TYM NAZEWNICTWEM?}

W literaturze anglojęzycznej szeroko pojętą problematyką przestrzennych aspektów ekonomii zajmuje się jedna z jej dziedzin - spatial economy (spatial economics), w literaturze francuskiej - économique spatiale. Nazwa ta nie ma, jak dotąd, polskiego odpowiednika. Niektórzy znawcy zagadnienia są zdania, że w języku polskim trudno jest wyrazić zwięźle znaczenie tej nazwy. Istnieje również pogląd, że jeśli badania tego typu są prowadzone w obrębie nauk ekonomicznych, a ich przedmiotem jest część rzeczywistości ekonomicznej, właściwą nazwą jest ekonomika przestrzenna. Termin ten nie funkcjonuje jednak w literaturze przedmiotu (Domański 2002, s. 21). W literaturze polskiej zagadnienia te są dyskutowane $\mathrm{w}$ ramach geografii ekonomicznej i gospodarki przestrzennej.

Geografia ekonomiczna jest źródłem wiedzy o przestrzennym wymiarze gospodarki. Z tego względu, chociaż należy do zespołu nauk geograficznych, stała się zyskującym na znaczeniu elementem nauk ekonomicznych, a zwłaszcza nauk o zarządzaniu. Dziedzina ta wykorzystuje zarówno metody i narzędzia badawcze, jak i teorie ekonomiczne i społeczne do opisu oraz analizy przestrzennej organizacji gospodarki poszczególnych regionów (Kuciński, 2009, s. 16, 19). Przedmiotem geografii ekonomicznej są widziane w perspektywie przestrzennej uwarunkowania gospodarki - rozmieszczenie czynników produkcji i wzrostu gospodarczego, lokalizacja działalności gospodarczej (produkcji, wymiany, konsumpcji), związane z jej prowadzeniem powiązania i przepływy przestrzenne różnego rodzaju i skali (Kuciński, 2009, s. 9-10).

\footnotetext{
łość.

${ }^{1}$ Przestrzeń w tym kontekście jest rozumiana jako położenie geograficzne, sąsiedztwo, odleg-
} 
Gospodarka przestrzenna natomiast należy do zespołu nauk ekonomicznych. Jest to dziedzina zajmująca się badaniem minionego i aktualnego stanu zagospodarowania przestrzennego określonych obszarów (w zakresie środowiska, zaludnienia, osadnictwa, infrastruktury technicznej i gospodarki) oraz poszukująca ukrytych struktur decydujących o funkcjonowaniu całości. Ukryte struktury są tworzone poprzez wzajemne relacje i powiązania występujące pomiędzy poszczególnymi elementami przestrzeni. Kompleksowe ujęcie ukrytych struktur jest głównym celem badawczym gospodarki przestrzennej jako nauki, która tym w zasadzie różni się od geografii ekonomicznej. W ramach tej dziedziny wiedzy są poruszane zagadnienia z zakresu teorii lokalizacji, ośrodków centralnych, bazy ekonomicznej, struktury funkcjonalnej miast, regionu ekonomicznego, marshallowskich okręgów przemysłowych i polaryzacji (Dębski, 2005, s. 7-10).

Rozwój nauki i przenikanie się dyscyplin sprawia, że te same problemy są przedmiotem badania różnych dziedzin. Teorie, które zostaną przytoczone w dalszej części opracowania, są poruszane zarówno w ramach geografii ekonomicznej, jaki i gospodarki przestrzennej, szeroko dyskutowane są również w literaturze anglojęzycznej w ramach dziedziny spatial economy oraz wywodzących się z niej: regional economics, economic geography ${ }^{2} i$ new economic geography. W celu wprowadzenia ujednoliconego nazewnictwa dla całego nurtu badań związanych z przestrzennymi aspektami aktywności ekonomicznych i uporządkowania wiedzy w tym zakresie, w dalszej części artykułu będzie stosowany coraz częściej używany w polskiej literaturze termin - ekonomia przestrzenna.

\section{ROZWÓJ BADAŃ PRZESTRZENNYCH W TEORII EKONOMII}

Pierwsze wzmianki na temat badań nad przestrzennymi aspektami ekonomii można znaleźć w napisanym około 2000 lat temu artykule pt. Geographica autorstwa greckiego filozofa i geografa Strabo. Początkowo opis gospodarki był tylko jednym $\mathrm{z}$ elementów charakterystyki poszczególnych krajów, którego najważniejszą część stanowił opis zaawansowania wymiany handlowej. $Z$ czasem na znaczeniu zyskiwały studia dotyczące sukcesów bądź porażek gospodarek danych terytoriów. Zaczęto zastanawiać się nad znaczeniem lokalizacji działalności gospodarczych, problematyką rozwoju gospodarczego krajów oraz formowania się struktur przestrzennych gospodarek. Dzięki temu doceniono znaczenie przestrzennego wymiaru gospodarki, czyli uwarunkowań jej rozwoju wynikających z odmienności lokalizacji i przestrzennej organizacji (Kuciński, 2009, s. 15).

Pod koniec XIX w. i w pierwszej połowie XX w. znaczny wkład w rozwój ekonomii przestrzennej wnieśli: von Thünen (teorie lokalizacji), Weber (modele

\footnotetext{
${ }^{2} \mathrm{~W}$ literaturze przedmiotu zamiennie używana jest nazwa geographical economics (Fingleton, 2007, s. 2).
} 
lokalizacji przemysłu), Christaller (teoria rdzenia i peryferii), Hotelling (modele lokalizacji). W latach 40. XX w. Lösch rozwinął teorię lokalizacji. W jego koncepcji producenci i konsumenci, zasoby i wytwory, podział i konsumpcja tworzą spójny system regulowany przez rynek. Ponadto cały system jest przestrzennie uporządkowany. Ład przestrzenny, na który składają się współzależne i racjonalne lokalizacje przemysłu, rolnictwa i miast, został wyprowadzony z założeń dotyczących działania przedsiębiorstw i ludzi związanych z maksymalizacją zysku (Domański, 2002, s. 10). Lösch wprowadził również pojęcie $\mathrm{i}$ teorię regionu ekonomicznego. Teorię tę wyprowadził z przesłanek czysto ekonomicznych, abstrahując od administracyjnych i politycznych implikacji pojęcia regionu.

Przełomowym wydarzeniem dla rozwoju ekonomii przestrzennej było opublikowanie w 1953 r. artykułu pt. Exceptionalism in Geography: A Methodological Examination, w którym Schaeffer podkreślił, że analizy przestrzenne powinny mieć bardziej naukowy charakter, powinny wykorzystywać metody ilościowe (Schaeffer, 1953, s. 226-245). Schaeffer zmarł przed publikacją artykułu, nie mógł więc rozwijać proponowanego podejścia ani polemizować z krytyka, jednak jego następcy - Garrison (zagadnienia transportowe, innowacje), Barry (teorie rozwoju urbanistycznego i regionalnego), Tobler (twórca pierwszego prawa analiz przestrzennych) oraz Bunge (aplikacja geometrii w teorii geografii) - zaczęli wykorzystywać metody ilościowe i modele ekonometryczne w analizach przestrzennych (Suchecki, 2010, s. 203).

Zaproponowane przez Schaeffera podejście rozwijał w latach 60. i 70. $\mathrm{XX}$ w. Isard, który zapoczątkował kierunek badawczy zwany regionalistyka. Isard i jego następcy twierdzili, że jedynie dzięki wykorzystaniu metod ilościowych można nadać naukowy i uniwersalny charakter badaniom nad przestrzennymi aspektami gospodarki. Podkreślali potrzebę opracowania nowych, efektywniejszych metod badania oraz modelowania gospodarki miast i regionów, aby wypełnić lukę między tym, co oferowała ówczesna teoria ekonomii i geografia opisowa. Drugą, oprócz matematyzacji, charakterystyczną cechą regionalistyki było rozszerzenie problematyki badań miejskich i regionalnych. Problematykę ekonomiczną uzupełniono zagadnieniami urbanistycznymi, demograficznymi, społecznymi, kulturowymi, politycznymi i środowiskowymi. Nadało to nowemu kierunkowi badan charakter wielodyscyplinowy, co odpowiadało złożonej naturze miast i regionów oraz przyciagało do nowych idei specjalistów z różnych dziedzin (Domański, 2002, s. 11). Dzięki Isardowi wzrosło zainteresowanie efektami sąsiedztwa w socjologii ${ }^{3}$. Teoria interakcji społecznych zmusiła naukowców do analizowania zależności i powiązań przestrzennych, co w konsekwencji doprowadziło do powstania ekonometrii przestrzennej (Florax, Van der Vlist, 2003, s. 226).

\footnotetext{
${ }^{3}$ W późniejszych latach „rewolucji” Dixita oraz Stiglitza (1977) ugruntowano przekonanie o tym, jak ważną rolę odgrywają efekty sąsiedztwa w teorii socjologii.
} 
W latach 90. XX w., w których nastapił swoistego rodzaju renesans ekonomii przestrzennej, szczególną uwagę zwrócono na problemy rozwoju gospodarczego (nierówności w rozwoju gospodarczym regionów); globalizacji; międzynarodowej integracji gospodarczej; innowacyjności i konkurencyjności regionów; zróżnicowania przestrzennego zjawisk gospodarczych, politycznych i społecznych; przepływu dóbr, usług, kapitału, informacji, ludzi i podmiotów gospodarczych. Wprowadzono pojęcie kapitału społecznego, który ma znaczny wpływ na warunki prowadzenia działalności gospodarczych. Zyskano tym samym nowe narzędzie służące do objaśnienia specyfiki organizacji przestrzennej gospodarki (Kuciński, 2009, s. 22). W tym okresie powstała również jedna z najważniejszych obecnie dziedzin ekonomii przestrzennej - nowa ekonomia geograficzna ${ }^{4}$, której prekursorem był Krugman (zob. rys. 1).

Współcześnie ekonomia przestrzenna zwraca uwagę na kwestie etyczne i moralne, którymi kierują się ludzie podejmując działalności gospodarcze oraz wybierając dla nich lokalizacje. Zróżnicowanie przestrzenne zjawisk gospodarczych tłumaczy poprzez niejednorodność towarzyszących im warunków kulturowych, politycznych i historycznych. Szczególną wagę przywiązuje również do kwestii podziału przestrzeni ekonomicznej na jednostki przestrzenne (tzw. skale geograficzne). Podejście to nabrało znaczenia w ostatnich latach, kiedy zyskała na znaczeniu problematyka rozwoju regionalnego i lokalnego, dokonującego się w warunkach powszechnie panującej globalizacji (Kuciński, 2009, s. 23-25).

\subsection{REGIONALISTYKA}

Regionalistyka jest dziedziną nauk ekonomiczno-społecznych, której teorie analizują problemy związane z sytuacją gospodarczą występującą na danym terytorium (tj. miasto, wieś, gmina czy region). W ramach regionalistyki poruszane są problemy z zakresu teorii lokalizacji, transportu, rynku pracy, migracji, rozwoju miast, użytkowania ziemi, rozwoju przemysłu, ochrony środowiska przyrodniczego, ekologii, gospodarowania zasobami naturalnymi, polityki miejskiej i regionalnej, geograficznych systemów informacyjnych oraz analizy danych przestrzennych. Ogólnie rzecz ujmując, każdy rodzaj analizy ekonomiczno-społecznej, który posiada wymiar przestrzenny, może być rozpatrywany w ramach regionalistyki.

\footnotetext{
${ }^{4} \mathrm{~W}$ literaturze anglojęzycznej dziedzina ta nosi nazwę New Economic Geography (NEG), natomiast w tekstach francuskich funkcjonuje nazwa Économie Géographique. W książce pod redakcją Sucheckiego (2010) proponowane jest przyjęcie nazwy „nowa ekonomia geograficzna”, z uwagi na to, że dziedzina ta wywodzi się z nauk ekonomicznych i została zapoczątkowana przez ekonomistów, nie zaś geografów, którzy poddali jej teorie szerokiej krytyce (Fingleton, 2007, s. 1). Nazwa ta umożliwia dodatkowo stosowanie skrótu NEG, powszechnie rozpoznawanego i używanego w literaturze przedmiotu.
} 


\begin{tabular}{|c|c|c|}
\hline \multicolumn{3}{|c|}{ Koniec XIX i początek XX wieku } \\
\hline J.H. von Thünen & \multirow{4}{*}{$\begin{array}{l}\vec{b} \\
\vec{b} \\
\vec{b}\end{array}$} & \multirow{2}{*}{\begin{tabular}{|l} 
teorie lokalizacji \\
modele lokalizacji przemysłu
\end{tabular}} \\
\hline A. Weber & & \\
\hline W. Christaller & & teoria rdzenia i peryferii \\
\hline H. Hotelling & & modele lokalizacji \\
\hline \multicolumn{3}{|c|}{ Lata pięćdziesiąte XX wieku } \\
\hline F.K. Schaeffer & \multirow{5}{*}{$\begin{array}{l}\vec{b} \\
\vec{b} \\
\vec{b} \\
\vec{b}\end{array}$} & podejście ilościowe w ekonomii przestrzennej \\
\hline W.L. Garrison & & zagadnienia transportowe, innowacje \\
\hline B. Barry & & teorie rozwoju urbanistycznegoi regionalnego \\
\hline W.R. Tobler & & pierwsze prawo analiz przestrzennych \\
\hline W.W. Bunge & & aplikacja geometrii do teorii geografii \\
\hline \multicolumn{3}{|c|}{ Lata sześćdziesiąte i siedemdziesiąte XX wieku } \\
\hline W. Isard & $\vec{b}$ & regionalistyka \\
\hline \multicolumn{3}{|c|}{ Lata dziewięćdziesiąte XX wieku } \\
\hline P.R. Krugman & $\Rightarrow$ & nowa ekonomia geograficzna \\
\hline
\end{tabular}

Rysunek 1. Rozwój ekonomii przestrzennej w XX w.

Źródło: opracowanie własne.

Początki nauk regionalnych sięgają lat $30 . \mathrm{XX}$ w. W tym czasie Christaller (1933), Palander (1935), Hoover (1938) jako pierwsi zajęli się regionalnymi analizami ekonomicznymi i zaczęli rozwijać metodologię w tym zakresie. W latach 50. znaczny wkład w rozwój tej dziedziny wiedzy wnieśli Chamberlin (teoria konkurencji monopolistycznej), Perroux (ekonomia przestrzenna), Hagerstrand (badanie zależności pomiędzy naturą a społeczeństwem), Dunn (lokalizacja produkcji rolniczej), Lösch (ekonomia lokalizacji), Beckmann, McGuire, Wiinston (ekonomia transportu), Myrdal (ekonomia rozwijających się regionów), Hirshman (strategia rozwoju ekonomicznego), Ponsard (ekonomiczna analiza przestrzenna).

Niemniej jednak za ojca regionalistyki i najważniejszego jej przedstawiciela uważany jest Isard, który w 1956 r. w książce pt. Location and Space Economy: a General Theory Relating to Industrial Location, Market Areas, Land Use, Trade and Urban Structure zebrał i rozszerzył wcześniej prezentowane teorie. W pozycji tej promował również obiektywną i naukową analizę osadnictwa, lokalizacji przemysłu oraz rozwoju miejskiego. Za sprawą opublikowanej 
w 1960 r. książki pt.: Methods of Regional Analysis ugruntował swoją pozycję, jako jednego z najwybitniejszych przedstawicieli tej myśli.

Podstawowymi zagadnieniami rozważanymi w ramach regionalistyki są:

- czynniki wzrostu gospodarczego i rozwoju regionalnego,

- stabilność ekonomiczna regionów (w tym rynków pracy),

- konwergencja i dywergencja regionalna,

- krajowe i regionalne determinanty lokalizacji przemysłu,

- wpływ kondycji regionu na liczbę zlokalizowanych w nim firm,

- determinanty migracji ludności,

- regionalna specjalizacja i wymiana,

- dywersyfikacja gospodarki regionu,

- wpływ zanieczyszczenia środowiska naturalnego na zmiany ekonomiczne i społeczne w regionie,

- wpływ warunków geograficznych na kondycję ekonomiczno-społeczną w regionie,

- decentralizacja władzy - lokalne rozwiązania dla lokalnych problemów.

Stabilność ekonomiczna regionów jest jednym z głównych tematów dyskutowanych $\mathrm{w}$ ramach nauk regionalnych. Jest ona niezwykle istotna $\mathrm{z}$ punktu widzenia polityki regionalnej, ponieważ wpływa na potencjalny wzrost gospodarczy, stabilizację dochodów ludności oraz zmniejszenie poziomu bezrobocia. W myśl teorii ekonomii jednym ze sposobów osiąnnięcia stabilności ekonomicznej jest rozszerzenie i urozmaicenie prowadzonych w regionie działalności gospodarczych. Różnorodność aktywności ekonomicznych wymusza zróżnicowanie struktury gospodarczej regionu. Bardziej zróżnicowana gospodarka jest mniej wrażliwa na wahania spowodowane czynnikami zewnętrznymi (np. w krajach sąsiednich), potrafi się również z łatwością dostosować do nowych warunków panujących w kraju, a nawet przekwalifikować. Alternatywna teoria wskazuje natomiast, że przez specjalizację gospodarczą region może stać się na tyle konkurencyjny, by osiagnąć stabilizację ekonomiczną (Wagner, 2000, s. 1-4).

Kolejne ważne zagadnienia poruszane $\mathrm{w}$ ramach tej dziedziny wiedzy to wzrost i rozwój gospodarczy regionów ${ }^{5}$. Istnieje wiele teorii wyjaśniających mechanizmy rozwoju regionalnego. Można je podzielić na dwie zasadnicze grupy odpowiadające alternatywnym teoriom gospodarki. Do pierwszej grupy można zaliczyć koncepcje nurtu neoklasycznego, zakładające zgodnie z doktryną liberalną minimalizację interwencjonalizmu i traktujące wolny rynek jako mechanizm regulacyjny. Natomiast w skład drugiej grupy wchodzą koncepcje nurtu neokeynesowskiego traktujące interwencjonalizm jako niezbędny i naj-

\footnotetext{
${ }^{5}$ Wzrost gospodarczy wiąże się ze wzrostem produktu przypadającego na jednego mieszkańca i jest to zmiana ilościowa. Natomiast rozwój gospodarczy jest pojęciem szerszym i oznacza wzrost różnych aspektów życia człowieka, wśród których niektóre są niemierzalne, zatem jest to zmiana ilościowa i jakościowa. Wzrost jest podstawowym warunkiem rozwoju gospodarczego, którego poziom kształtuje warunki życia mieszkańców danego regionu.
} 
ważniejszy mechanizm regulacyjny i optymalizujący rozwój regionalny (Strahl, 2006, s. 22-26). Wedle teorii wyjaśniających mechanizmy wzrostu i rozwoju regionalnego są to procesy uwarunkowane przez wiele złożonych czynników (również przestrzennych), których oddziaływanie kumuluje się w procesie kształtowania sytuacji gospodarczej regionu.

Z pojęciami stabilności ekonomicznej i wzrostu gospodarczego bezpośrednio związane są zagadnienia konwergencji i dywergencji regionów, które są szeroko dyskutowane $\mathrm{w}$ ramach regionalistyki szczególnie w ostatnim dziesięcioleciu. Liczne teorie nauk regionalnych próbują wyjaśnić zjawisko nierównomiernego podziału dóbr w gospodarce oraz przyczyny pogłębiania się tych dysproporcji.

Przez konwergencję rozumiemy proces wyrównywania poziomu zmiennych ekonomicznych pomiędzy sąsiadującymi regionami, spowodowany szybszym rozwojem regionów biedniejszych. Konwergencja realna oznacza wyrównywanie się poziomów wzrostu gospodarczego regionów, najczęściej obrazowanego przez PKB per capita, mierzonego parytetem siły nabywczej. Liczne badania dowodzą, że w gospodarce światowej zachodzą zarówno procesy konwergencji, jak i dywergencji. Analizy regionów (krajów), które charakteryzują się podobnym poziomem rozwoju, potwierdzają występowanie zjawiska konwergencji. Natomiast wszystkie regiony (kraje) świata analizowane jednocześnie wskazują na ogólną tendencję do dywergencji. Oznacza to, że relatywny dochód w większości regionów świata oddala się od punktu odniesienia, jaki tworzą regiony rozwinięte (Gierczycka-Bednarek, 2007, s. 28).

Postępująca integracja w Europie oraz idące $\mathrm{z}$ nią w parze procesy liberalizacji gospodarczej czy otwieranie się krajów na wymianę międzynarodową prowadzą do występowania zjawiska konwergencji. Zjawisko to jest szczególnie widoczne w krajach Europy Środkowo-Wschodniej, gdzie regiony wykazuja wyraźną zbieżność w stosunku do krajów wysoko rozwiniętych, zarówno pod względem wyrównywania poziomu rozwoju gospodarczego, jak i synchronizacji wahań koniunktury. Przebieg transformacji zachodzaceej w Europie potwierdza zatem wnioski płynące z modelu „rdzenia i peryferii”, zgodnie z którym Europa Zachodnia stanowi rdzeń siły gospodarczej i kulturowej przyciagający do siebie peryferie, czyli słabiej rozwinięte regiony sąsiednie, leżące w Europie Środkowej i Wschodniej. Procesom tym sprzyja niewątpliwie swobodny przepływ kapitału, ludności, innowacji (nowych technologii), towarów oraz usług w ramach w Unii Europejskiej (Gierczycka-Bednarek, 2007, s. 30-33).

\subsection{NOWA EKONOMIA GEOGRAFICZNA}

Nowa ekonomia geograficzna wywodzi się z ekonomii rozwoju, ekonomii przestrzennej oraz ekonomii międzynarodowej. Źródeł rozwoju tej dziedziny wiedzy upatruje się w zapoczątkowanych w 1990 r. przez Portera rozważaniach nad konkurencyjnością krajów. Za prekursora nowej ekonomii geograficznej powszechnie uważany jest Krugman, który w 1991 r. wprowadził nowy nurt, 
prezentując model równowagi przestrzennej alokacji aktywności ekonomicznych. Nowością było tu wprowadzenie do modelu opisującego handel międzynarodowy czynnika łącznej międzyregionalnej mobilności siły roboczej. Szczególną uwagę zwrócono na rolę aspektów przestrzennych w procesie rozmieszczania aktywności ekonomicznych, które potraktowano jako zmienną endogeniczna.

Teoria Krugmana jest oparta na modelu konkurencji monopolistycznej Dixita i Stiglitza (1977), do którego wprowadzono mobilne czynniki produkcji oraz koszty transportu dóbr. Użycie pojęcia mobilności wymusiło postawienie pytania o tworzenie się skupisk aktywności ekonomicznych oraz o uwarunkowania, które wpływają na ich stabilność bądź niestabilność. Rysunek 2 przedstawia ideę tworzenia się aglomeracji, według której aby doszło do tego procesu musimy mieć do czynienia z co najmniej dwoma sassiednimi regionami, dwoma sektorami produkcji (rolniczym i przemysłowym) oraz dwoma rodzajami siły roboczej (rolnikami i pracownikami). Teoria zakłada, że w regionie pierwszym są produkowane wyroby rolnicze (mamy tu do czynienia ze stała produkcja), w drugim przemysłowe (tu produkcja wzrasta).

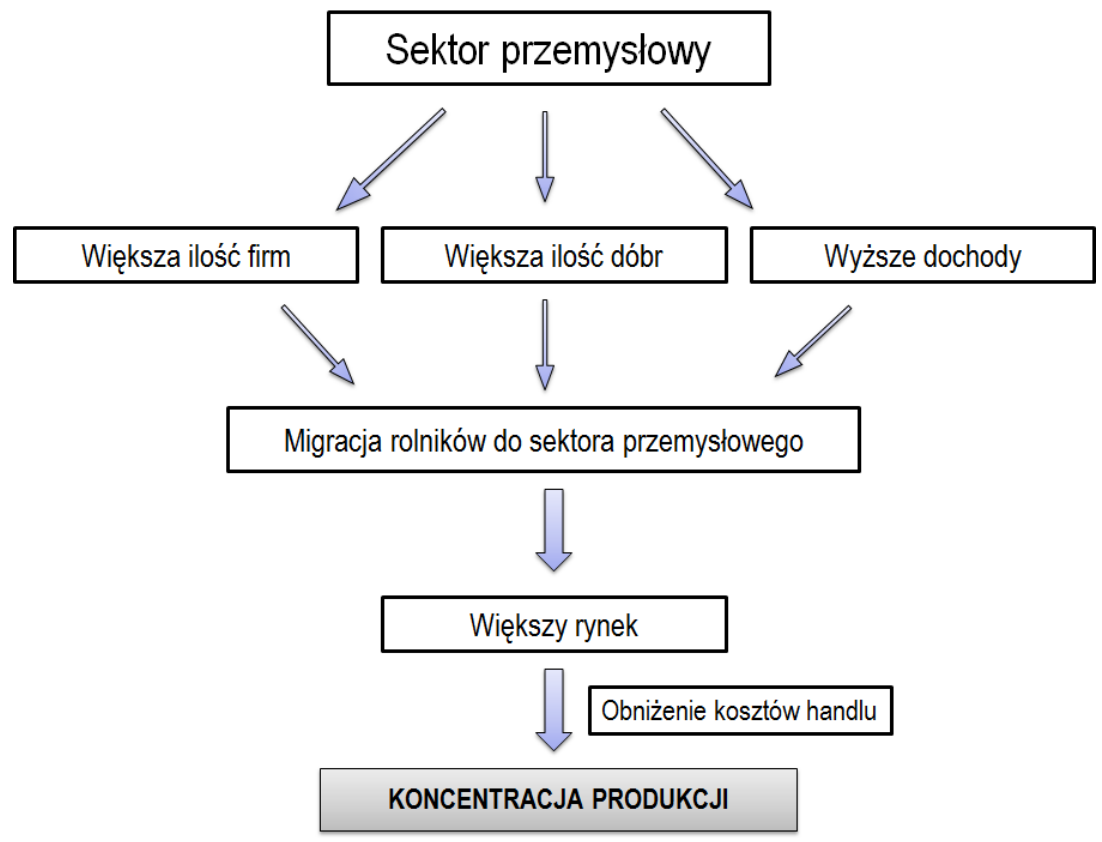

Rysunek 2. Proces tworzenia się aglomeracji

Źródło: opracowanie własne.

Pracownicy są mobilni pomiędzy regionami, rolnicy nie. Większa licyba firm jest zlokalizowana $\mathrm{w}$ regionie przemysłowym, w którym jest również wytwarzana większa ilość dóbr. Międzyregionalny handel dobrami przemysłowymi jest obciążony kosztami transportu, zatem rolnicy mają mniejszy dostęp do 
wytwarzanych w regionie przemysłowym dóbr. Sytuacja ta zachęca do migracji mieszkańców regionu rolniczego. Migracja rolników stwarza w regionie przemysłowym większy rynek. Powstaje więc bodziec do koncentracji produkcji (zob. rys. 2). Wysokie koszty transportu wymuszają koncentrację produkcji dóbr w regionie, w którym jest większy rynek zbytu. Należy podkreślić, że zasadniczą rolę w procesie rozwoju regionalnego odgrywają koszty handlu. Ich wysokość stymuluje, bądź też czyni nieopłacalnym proces aglomeracji. Wysokie koszty handlu powoduja, że koncentracja produkcji jest nieopłacalna, niskie natomiast zachęcają do aglomeracji (Suchecki, 2010, s. 206).

Jeśli napływy pracowników i producentów do regionu są wystarczająco silne gospodarka przyjmie model rdzenia i peryferii. Producenci skupiają się w jednym regionie, który jest rdzeniem, peryferie zaś stanowi nierozwinięty region rolniczy. Model taki może mieć miejsce, gdy koszty transportu wyrobów przemysłowych są stosunkowo niskie, wyroby wystarczająco zróżnicowane, a producenci uzyskują odpowiednio wysokie zyski (Suchecki, 2010, s. 207).

Należy podkreślić, że niewielka zmiana założonych w modelu uwarunkowań może spowodować przekształcenie gospodarki na taką, w której obydwa regiony są jednakowo rozwinięte. Niewielka ingerencja może również odwrócić sytuację regionów, w wyniku której rdzeniem stanie się region rolniczy. Mówimy wtedy o dynamicznym modelu ekonomicznym (Fujita, Krugman, 2004, s. 148).

Bodźcem, który powoduje dyspersję zjawisk ekonomicznych jest tzw. efekt zatłoczonego rynku. Firma przenosząca się do regionu, w którym jest większy rynek zbytu, powoduje zwiększenie liczby podmiotów gospodarczych na tym obszarze. Powstaje efekt zatłoczonego rynku, na którym jest większa konkurencja - konsumenci mają do wyboru większą ilość dóbr. Prowadzi to niekiedy do decyzji firmy o opuszczeniu regionu, dochodzi więc do dyspersji aktywności ekonomicznych (Suchecki, 2010, s. 207).

Opisana powyżej koncepcja, zaprezentowana w 1991 r. przez Krugmana i rozwijana pod koniec XX w. przez Krugmana, Fujita, Thisse oraz Baldwina, przyczyniła się do rozwoju nowego podejścia w ekonomii przestrzennej, w którym przestrzeń - lokalizację, potraktowano jako zmienną endogeniczną. Obecnie jednym $\mathrm{z}$ ważniejszych zagadnień poruszanych $\mathrm{w}$ ramach nowej ekonomii geograficznej jest globalizacja, która silnie wpływa na lokalizację, dystrybucję oraz charakter aktywności ekonomicznych na świecie. Kolejnym ważnym zagadnieniem jest poszukiwanie przyczyn nierównomiernego rozwoju ekonomicznego regionów. Teorie nowej ekonomii geograficznej dają świeże spojrzenie na problemy konwergencji i dywergencji regionalnej w świetle obecnych procesów globalizacyjnych. 


\section{ROZWÓJ METOD I MODELI ANALIZ PRZESTRZENNYCH}

Badania prowadzone w zakresie ekonomii przestrzennej były niewątpliwie impulsem dla rozwoju ekonometrii przestrzennej, która oferuje szeroki wachlarz metod i modeli służących do wykonywania analiz przestrzennych.

Ekonometria przestrzenna narodziła się w Europie na początku lat 70 . XX w. Jej prekursorem był Paelinck, który wprowadził pojęcie „ekonometria przestrzenna" w 1974 r., na posiedzeniu Holenderskiego Towarzystwa Statystycznego. Zaprezentowano wtedy pierwszą wizję nowej dziedziny wiedzy oraz przedstawiono pięć głównych zasad analiz przestrzennych, którymi są: współzależność przestrzenna, asymetria przestrzenna, allotopia, odmienne interakcje ex-ante i ex-post oraz obecność zmiennych zlokalizowanych w modelowaniu przestrzeni (Anselin, 1988, s. 7).

W 1979 r. Tobler sformułował tzw. pierwsze prawo geografii, które jest obecnie podstawą wszelkich analiz przestrzennych, brzmi ono następująco: „wszystko jest powiązane ze sobą, jednak bliższe obiekty są bardziej zależne od siebie niż odległe" . W ten sposób wprowadził pojęcie zależności przestrzennych. W tym samym roku Paelinck i Klaasen, w pierwszej pozycji książkowej poświęconej w całości zagadnieniom z zakresu ekonometrii przestrzennej, podkreślili znaczenie przestrzennego modelowania zmiennych ekonomicznych. Zwrócili uwagę na fakt, iż poszczególne jednostki przestrzenne (np. regiony) podlegają wpływom innych jednostek oraz zależą od zachodzących tam zmian ekonomicznych, społecznych i politycznych. Zauważyli, że uwzględnienie aspektów przestrzennych w modelowaniu ekonometrycznym pozwoli:

1. uzyskać bardziej szczegółowe informacje na temat systemów ekonomicznych,

2. uniknąć problemów wynikających ze struktury danych przestrzennych (heterogeniczność przestrzenna) oraz powstających na skutek wprowadzenia efektów przestrzennych do modelu ekonometrycznego (autokorelacja przestrzenna).

Łącząc metody ekonometrii, ekonomii przestrzennej oraz geografii, zapoczątkowali rozwój nowej dziedziny wiedzy - ekonometrii przestrzennej (Suchecki, 2010, s. 16).

Pierwsze testy i metody estymacji modeli ekonometrycznych uwzględniających aspekt przestrzenny powstały w latach 70. i 80. XX w. Wprowadzono wtedy pojęcia interakcji przestrzennych, efektów przestrzennych, autokorelacji i heterogeniczności przestrzennej oraz obrazów przestrzennych. W 1988 r. Anselin opublikował monografię pt. Spatial Econometrics: Methods and Models, która stała się najbardziej znaczącą pozycją, omawiającą kompleksowo zagadnienia z zakresu ekonometrii przestrzennej. W książce tej Anselin zdefiniował ekonometrię przestrzenną jako naukę, której celem jest opis zjawisk i procesów gospodarczych posiadających aspekt przestrzenny za pomocą metod ilościo-

\footnotetext{
${ }^{6}$ Orginalne brzmienie prawa: Everything is related to everything else, but near things are more related than distant things.
} 
wych oraz zbiór technik, dzięki którym można uniknąć problemów metodologicznych powstających na skutek wprowadzenia efektów przestrzennych do modelu ekonometrycznego. Anselin podkreślił również, że dziedzina ta umożliwia badanie interakcji zachodzących $\mathrm{w}$ przestrzeni, wyodrębnianie efektów grupowych oraz efektów sąsiedztwa, analizowanie wpływu poszczególnych jednostek przestrzeni na ogólny poziom badanej cechy (Anselin, 1988, s. 7).

Początkowo metody ekonometrii przestrzennej były wykorzystywane jedynie w badaniach regionalnych, analizach rynku nieruchomości i ekonomii przestrzennej. Jednakże w latach 90 . XX w., gdy przestrzeń zaczęła odgrywać bardzo ważną rolę w teorii ekonomii, wzrosło zainteresowanie testowaniem występowania zależności przestrzennych oraz budową modeli ekonometrycznych uwzględniających te zależności. Nastąpił szybki rozwój metod ekonometrii przestrzennej. Pojawiła się fachowa literatura przedmiotu w postaci publikacji książkowych poświęconych $\mathrm{w}$ całości zagadnieniom $\mathrm{z}$ zakresu analiz przestrzennych, np.: Anselin, Florax (1995), Getis, Mur, Zoller (2003), Arbia, Baltagi (2008), LeSage, Kelley Pace (2009).

Na przełomie XX i XXI w. opracowano specjalistyczne oprogramowanie komputerowe umożliwiające analizy danych przestrzennych i przestrzennoczasowych z wykorzystywaniem technik ekonometrii przestrzennej. Pierwszym programem był SpaceStat, którego kolejne wersje ukazały się w latach 1991, 1995,1998 i 2001 . W 2000 r. powstały moduły z funkcjami do analiz przestrzennych opracowane przez LeSage'a i Bivanda, dla programu Matlab (Spatial Econometrics Toolbox), oraz Bivanda i Reya dla programu R CRAN (spdep). W 2003 r. ukazał się ogólnodostępny program GeoDa opracowany przez Anselina. W 2010 r. Anselin i Ray wprowadzili ogólnodostępny pakiet PySAL, który integruje dwa narzędzia analityczne wykorzystywane w badaniach przestrzennych - STARS oraz PySpace. Wiele gotowych procedur i funkcji napisanych w językach Matlab i R CRAN jest ogólnie dostępnych w Internecie na zasadach open source.

Szybki rozwój metod i modeli sprawił, że obszar zastosowań narzędzi ekonometrii przestrzennej jest bardzo szeroki, związany z najnowszymi kierunkami badań ekonomiczno-społecznych, tj. rozwojem gospodarczym regionów, dyfuzją innowacji, migracjami, transportem, ochroną środowiska, opieką zdrowotna, efektami sąsiedztwa, rynkiem nieruchomości, rynkiem pracy, interakcjami społecznymi.

Najnowsze kierunki badań w dziedzinie ekonometrii przestrzennej są związane $\mathrm{z}$ budową przestrzennych modeli panelowych i wielorównaniowych, prognozowaniem na podstawie danych przestrzenno-czasowych, efektami przestrzennymi w modelach nieliniowych, logitowych i probitowych, badaniem niestacjonarności i kointegracji danych przestrzenno-czasowych. Poruszane są również zagadnienia dotyczące zakresu i siły interakcji przestrzennych oraz budowy ekonomicznych macierzy wag przestrzenno-czasowych. 


\section{PODSUMOWANIE}

W literaturze przedmiotu wskazuje się, że twierdzenia teorii ekonomii pomijające wymiary przestrzenne są niepełne i przedstawiają rzeczywistość w zbytnim uproszczeniu (Domański, 2002, s. 9). Z tego względu metody ekonomii przestrzennej zyskują obecnie na znaczeniu. Stosowanie ich w badaniach dotyczących np. dyfuzji innowacji, rozwoju ekonomicznego regionów, transportu, handlu międzynarodowego, rynku nieruchomości, rynku pracy, ekonomicznych aspektów ochrony środowiska czy globalizacji ma ogromne znaczenie ze względu na fakt usytuowania analizowanych zjawisk w określonej przestrzeni geograficznej. Przestrzeń ta - położenie geograficzne, sąsiedztwo, odległość oraz powiązania przestrzenne między badanymi jednostkami terytorialnymi - ma zasadniczy wpływ na kształtowanie się owych zjawisk i procesów ekonomicznych.

Należy pamiętać, że zastosowanie narzędzi ekonometrii przestrzennej w analizach opartych na danych przestrzennych i przestrzenno-czasowych ma kluczowe znaczenie. Metody te nie tylko umożliwiają uzyskanie niezwykle cennych informacji na temat zależności przestrzennych występujących pomiędzy badanymi obszarami, ich stosowanie jest również bardzo istotne z punktu widzenia modelowania ekonometrycznego (estymacji parametrów).

\section{LITERATURA}

Anselin L. (1988), Spatial Econometrics: Methods and Models, Kluwer Academic Publishers, Dordrecht.

Anselin L., Florax R. J. (red.) (1995), New Directions in Spatial Econometrics, Springer-Verlag, Berlin.

Arbia G., Baltagi B. H. (red.) (2008), Spatial Econometrics. Methods and Applications, Physica-Verlag Heidelberg, Berlin.

Christaller W. (1933), Die Zentralen Orte in Süddeutschland. Eine ökonomisch-geographie Untersuchung über die Gesetzmässigkeit der Vorbereitung und Entwicklung der Siedlungen mit städtischen Funktionen, Jena.

Dębski J. (2005), Gospodarka przestrzenna jako nauka, t. 2, Wydawnictwo Wyższej Szkoły Finansów i Zarządzania w Białymstoku, Białystok.

Dixit A. K., Stiglitz J. E. (1977), Monopolistic Competition and Optimum Product Diversity, „American Economic Reviev”, 67, 297-308.

Domański R., (2002), Gospodarka Przestrzenna, PWN, Warszawa.

Fingleton B. (red.) (2007), New Directions in Economic Geography, Edward Elgar, Cheltenham, UK.

Florax R. J., Van der Vlist A. J. (2003), Spatial Econometric Data Analysis: Moving Beyond Traditional Models, „International Regional Science Review”, 26(3), 223-243, DOI: http://dx.doi.org/10.1177/0160017603254937

Fujita M., Krugman P. R. (2004), The new economic geography: past, present and the future, „Papers in Regional Science”, 83, 139-164, DOI: http://dx.doi.org/10.1007/978-3-66207223-3 6

Getis A., Mur J., Zoller H. (red.) (2003), Spatial Econometrics and Spatial Statistics, Palgrave Macmillan

Gierczycka-Bednarek A. (2007), Konwergencja czy dywergencja we wspótczesnej gospodarce światowej, [w:] Kopycińska D. (red.), Działania ekonomiczne podmiotów rynkowych materiaty konferencyjne, Katedra Mikroekonomii Uniwersytetu Szczecińskiego, 28-37. 
Hoover E. M. (1938), Location Theory and the Shoe and Leather Industries, Harvard University Press, Cambridge Mass.

Isard W. (1956), Location and Space Economy: a General Theory Relating to Industrial Location, Market Areas, Land use, Trade and Urban Structure, The IMT Press, Cambridge.

Isard W. (1960), Methods of Regional Analysis, Technology Press of Massachusetts Institute of Technology and Wiley, New York.

Krugman P. (1991), Increasing returns and economic geography, „Journal of Political Economy”, 99(3), 483-499, DOI: http://dx.doi.org/10.1086/261763.

Kuciński K. (red.) (2009), Geografia ekonomiczna, Wolters Kluwer Polska, Kraków.

LeSage J., Kelley Pace R. (2009), Introduction to Spatial Econometrics, Chapman \& Hall.

Paelinck J. H. P., Klaassen, L. H. (1979), Spatial Econometrics, Saxon House, Farnborough; wydanie polskie: Ekonometria przestrzenna (1983), PWN, Warszawa.

Palander T. (1935), Beitrage zur Standortstheorie, Upsala.

Schaefer F. K. (1953), Exceptionalism in Geography: A Methodological Examination, „Annals of the Association of American Geographers", 43, 226-245, DOI: http://dx.doi.org/10.2307/ 2560876.

Strahl D. (2006), Metody oceny rozwoju regionalnego, Wydawnictwo Akademii Ekonomicznej im. Oskara Langego we Wrocławiu, Wrocław.

Suchecki B. (red.) (2010), Ekonometria Przestrzenna. Metody i modele analizy danych przestrzennych, Wydawnictwo C.H. Beck, Warszawa.

Tobler W. (1979), Cellular Geography, [w:] Gale S., Olsson G. (red.), Philosophy in Geography, Reidel, Dordrecht, 379-386, DOI: http://dx.doi.org/10.1007/978-94-009-9394-5 18.

Wagner J. E. (2000), Regional Economic Diversity: Action, Concept or State of Conclusion, „The Journal of Regional Analysis and Policy", 30(2), 1-22.

\section{THE ROLE OF SPACE IN ECONOMIC RESEARCH}

A b s t r a c t. The aim of the paper is to underline the role of space (understood as geographical location, neighborhood, distance between spatial units) in economic research. This article presents selected theories from disciplines such as spatial economy, new economic geography and regional science that gave an inspiration for development of contemporary spatial analysis methods and models.

K e y w o r d s: space, spatial economy, spatial data analysis. 